\title{
Antioxidant Activity of Mytilus galloprovincialis and Ruditapes philippinarum ${ }^{\#}$
}

\author{
Serhat Çolakoğlu ${ }^{1, a}$, Gülen Türker ${ }^{2, b}$, İlknur Ak ${ }^{3, c}$, Fatma Çolakoğlu ${ }^{2, d, *}$ \\ ${ }^{1}$ Department of Food Processing, Çanakkale School of Technical Sciences, Çanakkale Onsekiz Mart University, 17100 Çanakkale, Turkey \\ ${ }^{2}$ Department of Food Technology, Çanakkale School of Applied Sciences, Çanakkale Onsekiz Mart University, 17100 Çanakkale, Turkey \\ ${ }^{3}$ Department of Aquaculture, Faculty of Marine Sciences and Technology, Çanakkale Onsekiz Mart University, 17100 Çanakkale, Turkey \\ * Corresponding author
}

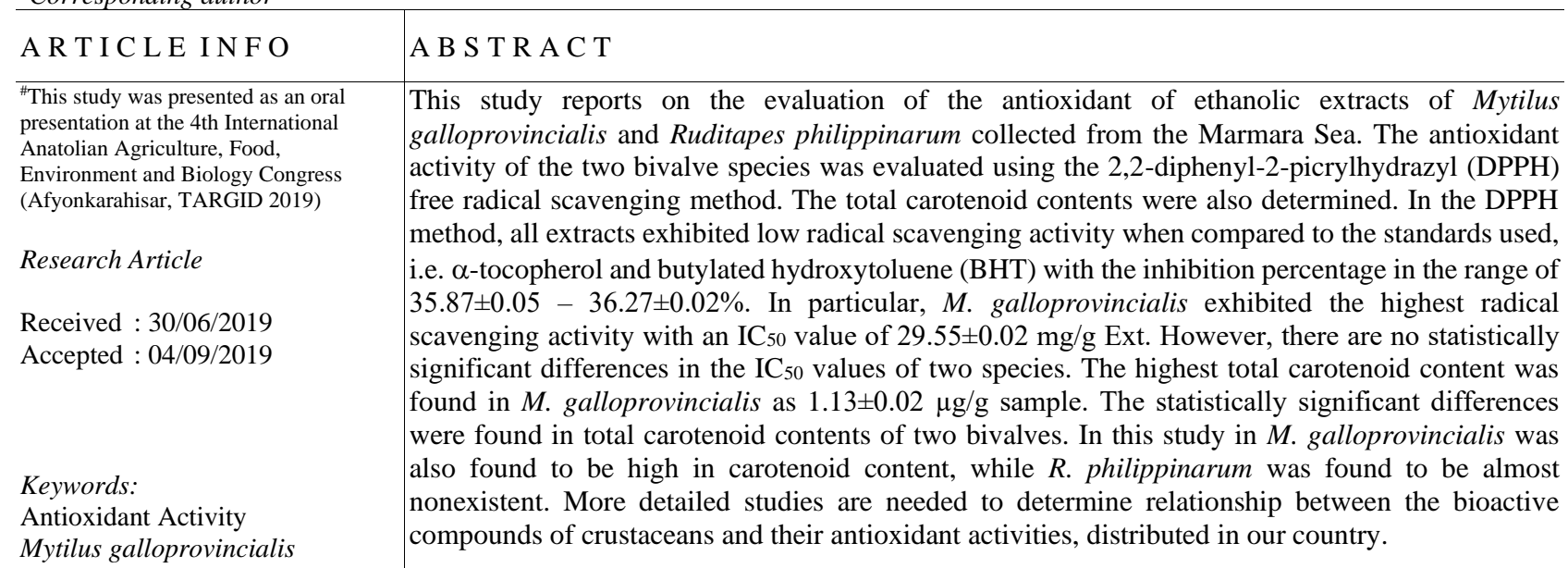

Ruditapes philippinarum

Total Carotenoids

DPPH

\section{Introduction}

Bivalve molluscs are harvested commercially and are of considerable significance for aquaculture. They are important food resources that contribute considerable economic value to the world's fisheries (Leiva and Castilla 2002). It has been recognized as a high- quality nutritious food and is considered a delectable. The bivalves are among the most harvested species in the world, as well as in Turkey (FAO, 2009). In recent years in Turkey, bivalves were harvested, which represents $5 \%$ of the total fisheries production (TUIK 2010). The main production areas of bivalves are the west Black Sea and the Marmara Sea in Turkey.

M. galloprovincialis called Mediterranean mussel is distributed in the Mediterranean Sea and the Black Sea, and the Atlantic coasts (Mathiesen et al., 2017). It lives on all coasts that have hard substrates within sheltered harbors and estuaries and on rocky shores of the open coast (FAO, 2019). According to the official statistics of the National Agency for Fishery and Aquaculture (TUIK, 2010), natural beds of the Mediterranean mussel is abundance in our coastal zones and it is the only molluscs species cultivated in Turkey. The venerid clam Ruditapes philippinarum (Japanese carpet shell) inhabits sandy and muddy bottoms of seas and it is usually found buried $2-3 \mathrm{~cm}$ below the surface in the intertidal zone (Moschino et al.,2012). Natural populations of this species are distributed along the coast of the Pacific and Atlantic Oceans, as well as the coastlines of the Adriatic and Aegean Seas (Jensen et al., 2004), and along the coast of the Mediterranean and Marmara Seas (Albayrak, 2005). $R$. philippinarum is one of the most economically important molluscs in the world and their commercial production comes from both fishing of natural stocks and cultivation (Çolakoğlu and Palaz, 2014).

The considerable amount of literature has been published on the nutritional composition of bivalves (Mooney et al. 2002; Orban et al., 2002; Dridi et al. 2007; 
Lorenz, 2010). They contain useful functional lipids, particularly proteins, and bioactive components. Especially mussels are rich on carotenoids, which act as antioxidants (Orban et al., 2002; Lorenz, 2010). In recent years, these aspects are classified as more valuable than most animal foods and therefore they are included in the category of "functional foods" (Alasalvar and Taylor, 2002; Shahidi and Naczk, 2004). Due to these facts, the importance of marine mussels as a source for bioactive substances with anti-inflammatory, antimicrobial, and lowering cholesterol level agents is increasing rapidly (Merdzhanova et al., 2017).

The carotenoids possess the high antioxidant potential and some studies report their use in preventing free-radicalinitiated diseases including atherosclerosis, cataracts, and age-related muscular degeneration (Perera and Yen, 2007). By predominantly feeding on aquatic plants, molluscs can accumulate carotenoids in their tissue. Many studies showed that carotenoids have also been linked to tolerance and adaptation to several stressful conditions in mussels (Bendich and Olson, 1989; Hill and Johnson, 2012; Anbazahan et al., 2014). Natural antioxidants as free radical scavengers are widely used in the food industry to enhance the sensory, health-promoting, or keeping quality of foods.

The aim of the present study is to determine the antioxidant activity and carotenoid of extracts obtained from Mytilus galloprovincialis and Ruditapes philippinarum collected from the Marmara Sea.

\section{Materials and Methods}

\section{Sample Collection}

Mytilus galloprovincialis and Ruditapes philippinarum were collected from natural beds located at the Southern Coast of Marmara Sea, Turkey. Collected samples were transported with ice after transportation of samples to the laboratory, each sample was inspected; dead, or damaged specimens were eliminated. Mean height and weight of samples were measured as $5.47 \pm 0.14 \mathrm{~g}$ and $80.76 \pm 44 \mathrm{~mm}$, $20.32 \pm 0.21$ and $37.01 \pm 0.14$, respectively. The samples were immediately frozen at $-20^{\circ} \mathrm{C}$ and stored in a fridge. All shucked mussels were cut into small pieces and they were homogenized at $800 \mathrm{rpm}$ for $5 \mathrm{~min}$, using a Molineux blender.

\section{Standards and Reagents}

All chemicals were purchased from Sigma-Aldrich (USA), SPA (Milan, Italy), Merck (Germany), and Fluka Chemie (Switzerland).

\section{DPPH Radical Scavenging Activity}

The DPPH (2,2-diphenyl-2-picrylhydrazyl) radical scavenging activity of the sample extract was measured according to the procedure described by Brand-Williams et al. (1995). Methanolic extracts were prepared in dilution series $(0.25$ to $1 \mathrm{mg} / \mathrm{ml}) .0 .1 \mathrm{ml}$ of each dilution was added to $3.0 \mathrm{ml}$ of a $6 \times 10^{-5} \mathrm{M}$ methanolic solution of DPPH followed by vortexing. The mixture was shaken vigorously and then it allowed standing in the dark at room temperature for $30 \mathrm{~min}$. The absorbance of the solution was measured spectrophotometrically (UV-Vis. Spectrophotometer, Thermo Aquamate) at $515 \mathrm{~nm}$ against methanol. The
DPPH radical scavenging activity (\%) was calculated using the following equation:

$\mathrm{DPPH}=\left[\left(\mathrm{A}_{\text {control }}-\mathrm{A}_{\text {sample }}\right) / \mathrm{A}_{\text {control }}\right]$ is the absorbance of the control.

Butylated hydroxytoluene (BHT) and $\alpha$-Tocopherol (Vitamin E) was used as a positive control. A lower value of $\mathrm{IC}_{50}$ indicates a higher antioxidant activity.

\section{The Analysis of Total Carotenoid Content}

The carotenoid content was determined spectrophotometrically (UV-Vis. Spectrophotometer, Thermo Aquamate) and the absorbance was measured at $450 \mathrm{~nm}$ according to Biehler et al. (2010). The average carotenoid concentrations $(\mathrm{mol} / \mathrm{L})$ were calculated with the following equation:

\section{$\mathrm{C}(\mathrm{Mol} / \mathrm{L})=\mathrm{A}_{450} \times \mathrm{Fd} / 135310$}

The $\mathrm{A}_{450}$ and $\mathrm{Fd}$ can be defined as the absorbance and the dilution factor at $450 \mathrm{~nm}$. $(1 \mathrm{~cm})$. The average concentrations $(\mathrm{C} \mathrm{mol} / \mathrm{L})$ were turned as micrograms per grams $(\mu \mathrm{g} / \mathrm{g}) .135310$ value is an average molar absorption coefficient to be calculated for ethanol solvent by Biehler et al. (2010).

\section{Statistical Analysis}

The significance of differences between IC50 values and \% Inhibition was determined by one-way analysis of variance (ANOVA) and the significance of differences between total carotenoid contents was measured by Student's $t$-test. Before ANOVA or Student's $t$-test, all data were checked for homogeneity of variance and normal distribution. A significant difference was considered at the level of $\mathrm{P}<0.05$.

\section{Results and Discussion}

Free radicals are inevitably produced in biological systems and encountered exogenously. They are known to cause various degenerative disorders, like mutagenesis, carcinogenesis, cardiovascular disturbances, and aging (Singh and Singh 2008). The importance of the antioxidant potential of carotenoids to human health derives from their potential to reduce the oxidative stress linked to various ROS related disorders and/or diseases (Voutilainen et al., 2006; Fiedor and Burda, 2012). Antioxidants are the compounds, which neutralize the free radicals by intervening at any one of the three major steps of the free radical-mediated oxidative process, viz., initiation, propagation, and termination (Cui et al., 2004). These antioxidants are also produced by a biological system and occur naturally in many foods and taken from food compounds to the body (Halliwell, 1996).

In the present investigation, we discuss the level of total carotenoids and radical scavenging activated level in shellfishes. In our study, it was found that these two molluscs species showed antioxidant properties and the carotenoid content was high. The scavenging activity of $M$. galloprovincialis and R. philippinarum on DPPH free radical are summarized in Table 1. These two bivalves have same $\mathrm{IC}_{50}$ values and they showed the low antioxidant potential (29.55 $\pm 0.02 \mathrm{mg} / \mathrm{g}$ Ext.). Our results are significantly lower than two commercial antioxidants 
tested, BHT and Vitamin $\mathrm{E}(\mathrm{P}<0.05)$. The antioxidant activities of two shellfish were not significantly different $(\mathrm{P}>0.05)$, and \% inhibition values ranged from $35.87 \pm 0.05$ to $36.27 \pm 0.02 \mathrm{mg} / \mathrm{g}$ of extract. Thus, both $M$. galloprovincialis and $R$. philippinarum showed medium potential DPPH radical scavenging activity.

The total carotenoid contents in the $M$. galloprovincialis and $R$. philippinarum are summarized in Table 2. The total carotenoid content varied between $0.03 \pm 0.07$ to $1.13 \pm 0.02 \mu \mathrm{g} / \mathrm{g}$ sample. The highest carotenoid content was detected in $M$. galloprovincialis. There is a significant difference between the total carotenoid content of two bivalves $(\mathrm{P}<0.05)$. Photosynthetic algae and plants, fungi and bacteria synthesize carotenoids while other organisms must either obtain the necessary carotenoids directly from the diet or modify the dietary carotenoid precursors through metabolic reactions. Carotenoid pigments are abundantly present in marine plants. Molluscs, such as bivalves, accumulate carotenoids obtained in their body tissues either directly from their dietary microalgae (e.g., fucoxanthin, diatoxanthin, diadinoxanthin, and alloxanthin) or after modification through metabolic reactions (Kantha, 1989; Liaaen-Jensen, 1998; Maoka and Akimoto, 2008). Metabolites derived from fucoxanthin like mytiloxanthin or crasssostreaxanthin are widely distributed in marine mussels and oysters (Matsuno, 1989; Liaaen-Jensen, 1998; Maoka and Akimoto, 2008). Astaxanthin is the main pigment in the body and eggs of crustaceans (van Nieuwerburgh et al., 2005).

Table 1 DPPH values of the M. galloprovincialis and R. philippinarum. Different lowercase letters show the significant differences between the groups according to the ANOVA results $(\mathrm{P}<0.05)$.

\begin{tabular}{l|rc}
\hline \multicolumn{1}{c}{ Species } & \multicolumn{1}{c}{${ }^{1} \mathrm{IC}_{50}$} & ${ }^{2} \%$ \\
\hline M. galloprovincialis & $29.55 \pm 0.02^{\mathrm{a}}$ & $35.87 \pm 0.05^{\mathrm{c}}$ \\
R. philippinarum & $29.55 \pm 0.07^{\mathrm{a}}$ & $36.27 \pm 0.02^{\mathrm{c}}$ \\
Butylated hydroxytoluene & $1.33 \pm 0.01^{\mathrm{c}}$ & $99.00 \pm 0.11^{\mathrm{a}}$ \\
$\alpha$-tocopherol & $1.48 \pm 0.02^{\mathrm{b}}$ & $96.00 \pm 0.15^{\mathrm{b}}$ \\
\hline
\end{tabular}

${ }^{1}$ Inhibition values (mg/g Ext.), ${ }^{2}$ Inhibition

Table 2 Total Carotenoid values of the M. galloprovincialis and R. philippinarum. Different lowercase letters show the significant differences between the groups according to the Student's t-test results $(\mathrm{P}<0.05)$.

\begin{tabular}{l|c}
\hline \multicolumn{1}{c|}{ Species } & $\begin{array}{c}\text { Total carotenoid values } \\
(\mu \mathrm{g} / \mathrm{g} \text { sample })\end{array}$ \\
\hline M. galloprovincialis & $1.13 \pm 0.02^{\mathrm{a}}$ \\
R. philippinarum & $0.03 \pm 0.07^{\mathrm{b}}$ \\
\hline
\end{tabular}

In organisms, especially shellfish, carotenoids, in the food web benefit from their protection against ultraviolet (UV) radiation, their antioxidant properties against reactive oxygen species (ROS) and free radicals (Maoka, 2011; Caramujo et al., 2012). They play an important role as precursors of transcription regulators and in the immune system (Bendich and Olson, 1989; von Schantz et al., 1999; Hill and Johnson, 2012; Anbazahan et al., 2014). Some of the carotenoids are metabolized into vitamin A derivatives in the molluscan tissues (Kantha, 1989). In this study in $M$. galloprovincialis was also found to be high in carotenoid content, while $R$. philippinarum was found to be almost nonexistent. Carotenoids are colored compounds that affect the color of food. They are responsible for shellfish for the yellow, orange, or red color, but there are many noncarotenoid pigments in them (Tanaka and Katayama, 1979). The data obtained in our study coincide with this finding. In M. galloprovincialis, the color of the flesh is visually darker, and the gonads are usually orange. The $R$. philippinarum is lighter in color. The fact that antioxidant activity obtained in $R$. philippinarum is equivalent to $M$. galloprovincialis data shows that this property is not only related to total carotenoid content. However, both species have moderate free radical scavenging activity.

\section{Conclusion}

Seafood offers important bioactive molecules that have advantages on the human body. They are used in many fields such as the drug, cosmetic, and food industries. Functional foods are developed from marine products since they are widely available, and they have the ability to prevent certain diseases and cure some illnesses. Various kinds of seafood especially shellfish are consumed as a nutritionally beneficial food. Consequently, more detailed studies are needed to determine relationship between the bioactive compounds of crustaceans and their antioxidant activities, distributed in our country.

\section{References}

Anbazahan SM, Mari LS, Yogeshwari G, Jagruthi C, Thirumurugan R, Arockiaraj J. 2014. Immune response and disease resistance of carotenoids supplementation diet in Cyprinus carpio against Aeromonas hydrophila. Fish Shellfish Immunol. 40, 9-13. DOI: 10.1016/j.fsi.2014.06.011

Albayrak S. 2005. First record of Tapes philippinarum (Adams and Reeve, 1850) (Bivalvia: Veneridae) from the Sea of Marmara. Zool Middle East 35(1):108-109. DOI: 10.1080/09397140.2005.10638113

Alasalvar C, Taylor Y. 2002. Seafoods -Quality Technology and Nutraceutical Applications. Springer-Verlag, Heidelberg, Germany, 508 pp:17-31. ISBN 978-3-662-09836-3

Bendich A, Olson JA. 1989. Biological actions of carotenoids. FASEB J. 3(8): 1927-1932. PMID: 2656356

Biehler E, Maye F, Hoffmann L, Krause E, Bohn T. 2010. Comparison of 3 Spectrophotometric Methods for Carotenoid Determination in Frequently Consumed Fruits and Vegetables. Journal of Food Science.75(1):C55-61. DOI: 10.1111/j.1750-3841.2009.01417.x.

Brand-Williams W, Cuvelier ME, Berset C. 1995. Use of a free radical method to evaluate antioxidant activity. LWT-Food Sci.Technol. 28(1): 25 - 30. DOI: 10.1016/S00236438(95)80008-5

Caramujo MJ, de Carvalho CC, Silva SJ, Carman KR. 2012. Dietary carotenoids regulate astaxanthin content of copepods and modulate their susceptibility to UV light and copper toxicity. Mar. Drugs 10(5):998-1018. DOI: 10.3390/md10050998

Cui K, Luo X, Murthy MRV. 2004. Role of oxidative stress in neurodegeneration: recent developments in assay methods for oxidative stress and nutraceutical antioxidants. Prog Neuropsychopharmacol Biol Psych. 28(5):771-799. DOI: 10.1016/j.pnpbp.2004.05.023

Çolakoğlu S, Palaz M. 2014. Some population parameters of Ruditapes philippinarum (Bivalvia, Veneridae) on the southern coast of the Marmara Sea, Turkey. Helgol Mar Res. 68(4): 539 - 548. DOI: /10.1007/s10152-014-0410-7 
Dridi S, Romdhane MS, Elcafsi M. 2007. Seasonal variation in weight and biochemical composition of the Pacific oyster, Crassostrea gigas in relation to the gametogenic cycle and environmental conditions of the Bizert Lagoon. Tunisia. Aquaculture. 263(1-4):238-248. DOI: 10.1016/j.aquaculture. 2006.10.028

FAO. 2009. Food and Agriculture Organization. State of the world fisheries and aquaculture, 2008. Rome: Fisheries and Aquaculture Department.

FAO. 2019. Fisheries and Aquaculture topics. Fisheries statistics and information. Topics Fact Sheets. In: FAO Fisheries and Aquaculture Department [online]. Rome. Updated 22 December 2015. [Cited 30 March 2019]. http://www.fao.org/fishery/

Fiedor J, Sulikowska A, Orzechowska A, Fiedor L, Burda K. 2012. Antioxidant effects of carotenoids in a model pigmentprotein complex. Acta Biochim. Pol. 59(1):61-64. PMID: 22428149

Halliwell B. 1996. Antioxidants in human health and disease. Annu Rev Nutr 16: 33- 50. DOI: 10.1146/annurev.nu. 16.070196.000341

Hill GE, Johnson JD. 2012. The vitamin A-redox hypothesis: a biochemical basis for honest signaling via carotenoid pigmentation. Amer. Nat. 180(5): E127-E150. DOI: $10.1086 / 667861$

Kantha SS. 1989. Carotenoids of Edible Molluscs; A Review. J. Food Biochemistry, 13, 429-442.DOI: 10.1111/j.17454514.1989.tb00410.x

Liaaen-Jensen S. 1998. Carotenoids in Food Chain, in Carotenoids: Biosynthesis and Metabolism, eds Britton G, Liaaen-Jensen S, Pfander H. (Basel: Birkhäuser), 359-371. ISBN: 9783764358297

Leiva GE, Castilla JC. 2001. A review of the world marine gastropod fishery: Evolution of catches, management and the Chilean experience. Reviews in Fish Biology and Fisheries 11(4):283-300. DOI: 10.1023/A:1021368216294

Lorenz T. 2010. A Review of the Carotenoid, Astaxanthin, as a Pigment Source and Vitamin for Cultured Penaeus Prawn, NatuRose Technical Bulletin 51. Pp: 1- 7. Available at: https://pdfs.semanticscholar.org/2322/b4bed5905f61477847 62713f82aaf254e7e3.pdf

Maoka T, Akimoto N. 2008. Carotenoids and their fatty acid esters of spiny lobster Panulirus japonicus. J. Oleo. Sci. 57(3): 145-152. PMID: 18270463

Maoka T. 2011. Carotenoids in marine animals. Mar. Drugs 9(2): 278-293. DOI: $10.3390 / \mathrm{md} 9020278$

Merdzhanova A, Dobreva DA, Panayotova V. 2018. Assessment of proximate and bioactive lipid composition of Black Sea Mussels (M. galloprovincialis) from Bulgaria. In: Biological Resources of Water. Ed: Ray S. Intech Open. London. ISBN: 978-1-78923-080-2, pp:181-200. DOI: 10.5772 /intechopen.71909
Moschino V, Delaney E, Da Ros L. 2012. Assessing the significance of Ruditapes philippinarum as a sentinel for sediment pollution: Bioaccumulation and biomarker responses. Environmental Pollution 171: 52 - 60 . DOI:10.1016/j.envpol.2012.07.024

Mathiesen SS, Thyrring J, Hemmer-Hansen J, Berge J, Sukhotin A, Leopold P, Bekaert M, Sejr MK, Nielsen EE. 2017. Genetic diversity and connectivity within Mytilus spp. in the subarctic and Arctic. Evolutionary Applications. 10:39-55. DOI: 10.1111/eva.12415

Matsuno, T., 1989. Animal Carotenoids, in Carotenoids: Chemistry and Biology, Eds: Krinsky NI, Mathews-Roth MM, Taylor RF.Springer. Boston pp:59-74. ISBN: 978-14613-0849-2

Mooney BD, Nichols PD, Elliot NG. 2002. Seafood the Good Food II: Oil profiles for further Australian seafood and influencing factors. Ed: Hobart T: CSIRO Division of Marine Research and Deakin, A.C.T.: Fisheries Research \& Development Corporation (FRDC), Australia. ISBN: 1876996064

Jensen AC, Humphreys J, Caldow RWG, Grisley C, Dyrynda PEJ. 2004. Naturalization of the Manila clam (Ruditapes philippinarum), an alien species, and establishment of a clam fishery within Poole Harbour, Dorset. J Mar Biol Assoc UK 84(5):1069-1073. DOI:10.1017/S0025315404010446h

Orban E, Di Lena G, Nevigato T, Casini I, Marzetti A, Caproni R., 2002. Seasonal changes in meat content, condition index and chemical composition of mussels (Mytilus galloprovincialis) cultured in two different Italian sites. Food Chemistry, 77(1): 57-65. DOI: 10.1016/S03088146(01)00322-3

Perera CO, Yen GM. 2007. Functional Properties of Carotenoids in Human Health, International Journal of Food Properties, 10:2, 201-230, DOI: 10.1080/10942910601045271

Shahidi F, Naczk M. 2004. Phenolics in Food and Nutraceuticals. CRC Press LLC, Florida. ISBN: 9781587161384 pp: $25-49$.

Singh S, Singh RP. 2008. In vitro methods of assay of antioxidants: An overview. Food Rev Int. 24(4):392-415. DOI: $10.1080 / 87559120802304269$

Tanaka Y, Katayama T. 1979. Carotenoids in Sea Mussel; Mytilus edulis. Mem. Fac. Fish., Kagoshima Univ. Vol. 28 : 9-16.

TUIK, 2010. Türkiye İstatistik Kurumu. Türkiye İstatistik Y1llığ 1 , 2009 Ankara, Yayın No:3436.

Van Nieuwerburgh L, Wänstrand I, Liu J, Snoeijs P. 2005. Astaxanthin production in marine pelagic copepods grazing on two different phytoplankton diets. J. Sea Res. 53(3): 147160. DOI: 10.1016/j.seares.2004.07.003

Von Schantz T, Bensch S, Grahn M, Hasselquist D, Wittzell H. 1999. Good genes, oxidative stress, and condition-dependent sexual signals. Proc. R. Soc. Lond. B. Biol. Sci. 266, 1-12.

Voutilainen S, Nurmi T, Mursu J, Rissanen TH. 2006. Carotenoids and cardiovascular health. Am. J. Clin. Nutr. 83(6):1265-1271. DOI: 10.1093/ajcn/83.6.1265 